\title{
LEADERS OF THE FOUR HUNDRED IN WORKS OF CICERO AND HIS ROMAN CONTEMPORARIES*
}

\author{
PAVEL NÝVLT
}

\begin{abstract}
The article analyses references to Pisander, Antiphon, Phrynichus and Theramenes in the writings of Cicero and Nepos. From a historian's point of view, the accuracy of the Romans' statements varies greatly and has to be evaluated in each instance separately. The Romans' opinions concerning the Greek politicians should be judged cautiously, because the Roman writers were not interested in giving an overall assessment of the Athenian oligarchs' political careers.
\end{abstract}

Keywords: Cicero; Cornelius Nepos; Roman literature; reception of Greek culture in Rome; ancient Greek history; ancient Greek historiography

The oligarchy of the Four Hundred established in Athens in 411 lasted only a short time and it seems to have slowly sunk into oblivion during the $4^{\text {th }}$ century even in Athens itself. ${ }^{1}$ Luckily for modern historians, Thucydides found the rise and fall of the Four Hundred fascinating, and went to great lengths to describe it. When he arrived at the formal establishment of the oligarchy in his narration, Thucydides stopped to present character sketches of the four leading figures of the oligarchy: Pisander, Antiphon, Phrynichus, and Theramenes. Much has been written about the lives of these men. Their posthumous reputations have received considerably less attention, although they have not been totally neglected by modern scholarship. ${ }^{2}$ However, no one has conducted a comprehensive study of how these men were regarded during the demise of the Roman Republic: the era

* This study came to light thanks to the long-term conceptual development of the Philosophical Institute of the Academy of Sciences of the Czech Republic (RVO: 67985955). All dates are BCE unless otherwise stated or obvious. I cannot presume to know any part of Roman history, let alone Cicero's writings, better than the dedicatee of this volume. I rather hope that this article might see the texts that are so familiar to him from a perspective that he might find interesting.

1 This resulted, at least in part, from the politics of remembrance and forgetting practiced by $4^{\text {th }}$-century Athenians, which has recently become a subject of several excellent studies, note esp. Shear (2011) and Steinbock (2013). Yet I think that this politics had less impact on the Romans' view of the leaders of the Four Hundred than Thucydides' work.

2 See Pesely (1983: 10-60) for Theramenes, Grossi (1984) for Phrynichus. I know of no systematic study of the posthumous reputations of Pisander or Antiphon. 
studied in great depth by the dedicatee of this volume; the era marked with no less chaos and bloodshed and no lower concentration of unique personalities than the last third of fifth century BCE in Greece. This suggests two interrelated questions: first, how much did the Romans know about the $5^{\text {th }}$-century Greece? Or, in other words, are the Roman sources reliable authorities for modern historians of ancient Greece? Second, what might the Romans have thought about the Greek oligarchs?

Pisander's name does not appear in the extant corpus of Cicero's works. The only Roman historian to mention him is Cornelius Nepos. In his life of Alcibiades, a part of his monumental treatise De viris illustribus, Nepos tells us that Pisander was contacted by Alcibiades when Alcibiades was trying to obtain leave to return to Athens in the winter of $412 / 11 .^{3}$ Nepos' narrative is easy to reconcile with the relevant passage of Thucydides, ${ }^{4}$ except for two rather important points. First, Nepos' phrase praetore, qui apud Samum exercitum habebat, is somewhat misleading. Nepos usually uses the word praetor to denote one of ten Athenian generals. Pisander did not hold the position and consequently did not have the command of the Athenian fleet on Samos. ${ }^{5}$

Should we wish to salvage Nepos' accuracy, we would have to make several assumptions. Perhaps Pisander had great unofficial influence with the sailors, possibly even greater than the generals. ${ }^{6}$ If this is what Nepos thought, the phrase qui apud Samum exercitum habebat could characterise the situation. However, we would then have to hypothesise that Nepos used the word praetor in the informal sense; but there is no evidence of such usage. ${ }^{7}$ It is thus preferable to conclude that Nepos chose not to go into detail here and oversimplified the situation.

Second and even more puzzling, Nepos claims that Pisander deserted Alcibiades. Having read the Thucydidean description of the negotiations between the Athenian oligarchs and Alcibiades (speaking for the Persian satrap Tissaphernes), one can hardly escape the conclusion that it was Alcibiades who deserted the oligarchs, not vice versa. ${ }^{8}$ It would seem that Nepos concentrated on Thucydides' statement oi 'A $\theta$ quaĩo ...

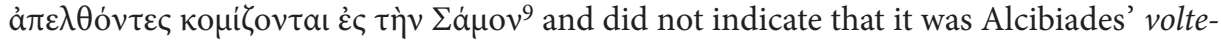
face that made them abandon the negotiations. In the paragraph we are discussing, Nepos concentrates on Alcibiades' abilities, rather than on his trickery. As a result, the image

3 Nep. Alc. 5, 3-4: initio cum Pisandro praetore, qui apud Samum exercitum habebat, per internuntios colloquitur et de reditu suo facit mentionem. is erat enim eodem quo Alcibiades sensu, populi potentiae non amicus et optimatium fautor. ab hoc destitutus primum per Thrasybulum, Lyci filium, ab exercitu recipitur.

4 Thuc. VIII, 47, 1-56, 5.

5 For Athenian generals in 412/11, see esp. Heftner (2001: 16-30). For Pisander, see Heftner (2001: 61-63).

6 This is made plausible by the success of the oligarchs in persuading the navy to negotiate with Alcibiades (Thuc. VIII, 48, 2-3). It is most likely that Pisander was involved in the rhetorical offensive.

7 See ThLL X/2, 1056, 68-1057, 73.

8 Thuc. VIII, 56. For an attempt to elucidate the passage see Nývlt (2014: 45-47), with references to which add Kriegel (1909: 26-27) and Monge (1995: 32-33), although I do not find their reconstructions convincing.

9 Thuc. VIII, 56, 5. 
of Pisander that emerges is rather tarnished. Nepos' opinion of Pisander clearly was not high, although more specific details are not available.

In Latin literature at the time of Cicero, there is only one unquestionable reference to Antiphon the Rhamnusian. Cicero mentions him in his brilliant history of oratory, in the dialogue Brutus, in a passage that summarises the dawn of Greek oratory and which has generated a good deal of controversy in Thucydidean scholarship. ${ }^{10}$ It is one of many bits of ancient evidence that led Luciano Canfora to the ingenious suggestion that Thucydides was present in Athens in 411. Canfora consequently proposed a drastic reassessment of the so-called second preface of Thucydides, ${ }^{11}$ claiming that it does not contain reliable evidence for Thucydides' twenty-year exile, but was written by Xenophon, along with a substantial part of Book Five. ${ }^{12}$ Canfora's theory had great influence in Italy, but was mostly ignored or rejected in the rest of the world. ${ }^{13}$ The main reason why it is difficult to agree with Canfora is that it seems unlikely that a posthumous editor (say, Xenophon), who must have approached the text of Thucydides with "religious care", ${ }^{14}$ would not have made his authorship of parts of the text clear in order not to impinge on legacy of the revered master.

And there is another argument against Canfora, more pertinent to the topic of this article: I am not persuaded that the whole of the crucial sentence quo neminem ... Thucydides comes from Aristotle, and I believe it is betrayed by the sudden intrusion of indicative scripsit into the chain of infinitives. ${ }^{15}$ Once robbed of their Aristotelian origin, the crucial words se audiente become Cicero's false inference from Thucydides' praise of Antiphon's self-defence, which on cursory reading does suggest Thucydides' presence. ${ }^{16}$ To make the statement about Antiphon's defence part of the Aristotelian text Cicero is paraphrasing, we would need to delete the word Thucydides, which seems no less inju-

10 For my purposes, it needs to be cited in a rather extensive context: Cic. Brut. 46-48: (46) Itaque, ait Aristoteles, cum sublatis in Sicilia tyrannis res privatae longo intervallo iudiciis repeterentur, tum primum, quod esset acuta illa gens et controversiae nata, artem et praecepta Siculos Coracem et Tisiam conscripsisse - nam antea neminem solitum via nec arte, sed accurate tamen et descripte plerosque dicere -; scriptasque fuisse et paratas a Protagora rerum illustrium disputationes, quae nunc communes appellantur loci. (47) quod idem fecisse Gorgiam, cum singularum rerum laudes vituperationesque conscripsisset, quod iudicaret hoc oratoris esse maxume proprium, rem augere posse laudando vituperandoque rursus adfligere; huic Antiphontem Rhamnusium similia quaedam habuisse conscripta; quo neminem umquam melius ullam oravisse capitis causam, cum se ipse defenderet se audiente, locuples auctor scripsit Thucydides. (48) Nam Lysiam primo profiteri solitum artem esse dicendi...

11 Thuc. V, 26.

12 Canfora (1970: passim). With slight alterations, Canfora restated his position many times; see, e. g., Canfora (1999; 2006: 13-17 and 22-23; 2011: 259-269).

13 Canfora's theory was accepted by Andriolo (2004: 86-89), and modified by Lapini (1991). For resolute disagreements, see, e. g., Dover (1981: 431-437) and Hornblower (2008: 50-53).

14 Canfora (2006: 22). For similar statements regarding the posthumous edition of Thucydides, not necessarily by Xenophon, see, e. g., Mewes (1868: 4 and 40); Wilamowitz-Moellendorff (1919: $955=1969$ : 404); Wade-Gery (1949: 903 = 1996: 1517).

15 It may very well be the case, as Canfora (1999: 36) states, that Quint. Inst. III, 1, 11 paraphrases the same Aristotelian text as Cic. Brut. 46-48. If so, it would rather be an argument against the Aristotelian origin of se audiente, for Quintilian cautiously states that Antiphon pro se dixisse optime est

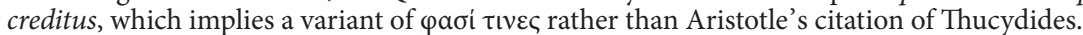

16 See Thuc. VIII, 68, 2. For this interpretation see, e. g., Hornblower (2008: 51), with references. 
dicious than Campe's deletion of se audiente rightly condemned by Canfora. ${ }^{17}$ Thus it appears that Cicero was mistaken in this particular instance and cannot serve as a reliable guide to Thucydides' whereabouts in 411 .

The fact that this is the only undisputed mention of Antiphon the Rhamnusian in Cicero's voluminous writings suggests that the Roman orator did not read Antiphon's speeches and knew him only from Thucydides and Aristotle, ${ }^{18}$ although it is equally possible that he had tried to read them, but found them too archaic and dull.

An Antiphon is repeatedly mentioned in Cicero's De divinatione as an imaginative dream-interpreter. ${ }^{19}$ It is not clear whether the author of the handbook on oneiromancy was identical with the Athenian oligarch, ${ }^{20}$ and Cicero's opinion on this matter is impossible to determine. Thus, we are left with a single reference and we cannot tell what Cicero thought about Antiphon, except that he considered him an orator skilful for his age.

The oligarch Phrynichus is not mentioned in any Latin text. ${ }^{21}$ The Romans seem to have followed the lead of the author of the Aristotelian Athenian Constitution, who probably bypassed Phrynichus in a sentence clearly inspired by Thucydides, offering only the names of the other three leaders of the oligarchy. ${ }^{22}$

We are in a much better position concerning Theramenes. To begin with, he is mentioned three times in Nepos' life of Alcibiades. The first two occurrences of his name are connected with the return of Alcibiades to Athens. Nepos, along with Diodorus, gives credit for Alcibiades' recall to Theramenes, ${ }^{23}$ while Plutarch ascribes it to Critias, and he even cites the latter's poem to corroborate his statement. ${ }^{24}$ Naturally, this engendered a long scholarly controversy: it is possible that Alcibiades was offered indemnity in the

17 Canfora (1999: 33-34).

18 Laughton (1961: 30).

19 Cic. Div. I, 39, I, 116 (in the latter place, Antiphon's name was deleted by Baiter, who is followed by Ax [1938], Giomini [1975: 66]; Pendrick [2002: 424]; and Wardle [2006: 387-388], but I am not sure the excision is necessary), and II, 144. The Antiphons mentioned in Cic. De orat. II, 242 and Cic. Att. IV, 15, 6 are the Athenian oligarch's unrelated namesakes.

20 Gagarin (2002: 99-101) is prone to accept the identification. Pendrick (2002: 24-26) follows ancient testimonies in ascribing the dream-book to Antiphon the sophist, whose identity with the oligarch he rejects (Pendrick 2002: 1-26); I do not find his opinion fully convincing, but this is not the place to pursue the issue.

21 Amm. XXVIII, 1, 4 mentions his namesake, the tragic poet older than Aeschylus.

22 [Arist.] Ath. 32, 2. Rhodes (1981: 408) suggests that the omission is due to a copyist rather than the author, but I prefer to follow Keaney (1980: 53-54) in believing that Phrynichus was bypassed because he did not fit among $\alpha \dot{\alpha} \delta \rho \tilde{\omega} v \ldots \gamma \varepsilon \gamma \varepsilon v \eta \mu \varepsilon \dot{\varepsilon} v \omega v \varepsilon \tilde{v}$ (I have to confess I do not know why the author of the Aristotelian treatise included this criterion in the text). For other attempts to explain the omission of Phrynichus, see esp. Grossi (1984: 82-83), with references; Shear (2011:36).

23 Nep. Alc. 5, 4 (primum per Thrasybulum, Lyci filium, ab exercitu recipitur [sc. Alcibiades] praetorque fit apud Samum, post suffragante Theramene populi scito restituitur parique absens imperio praeficitur simul cum Thrasybulo et Theramene); Diod. Sic. XIII, 38, 2 and 42, 1-2.

24 Plut. Alc. 33, 1 (and cf. Plut. Alc. 27, 1, where Plutarch does not mention who promoted the recall of Alcibiades). 
autumn of 411 on the motion of Critias and later, in 408 or 407, was formally called back and elected general on the motion of Theramenes; ${ }^{25}$ or that in 411 , Theramenes backed or even prompted the motion of Critias. ${ }^{26}$ Both these solutions assume that the Roman historian is right, although somewhat simplifying. Nepos then outlines the successes of Alcibiades, Thrasybulus, and Theramenes in the Hellespont without attributing their individual accomplishments. ${ }^{27}$ The third and final mention of Theramenes in Nepos' Alcibiades concerns Alcibiades' return home; Theramenes, according to Nepos, was totally eclipsed by Alcibiades, and there is no reason to doubt Nepos' account. ${ }^{28}$

Nepos thus seems to have been better informed about Theramenes than about Pisander. Nepos acknowledges the political and military abilities of the Athenian, but Theramenes did not merit his own biography in Nepos' collection of foreign generals, unlike Thrasybulus and Alcibiades. It cannot be excluded that in Nepos' De viris illustribus there was a book on foreign orators in which Theramenes might be included, ${ }^{29}$ but the lack of any reference to a book on Roman orators in the biography of Cato the Elder makes the existence of this pair of books highly unlikely.

Cicero does not describe Theramenes' political or military career, but in his Tusculan Disputations he devotes a long passage to recounting Theramenes' courage in the face of death: Theramenes threw the dregs of his hemlock extract out of his cup and then ironically offered a toast to Critias, the leading member of the Thirty Tyrants who pushed through Theramenes' execution. ${ }^{30}$

Our best source for this event is Xenophon, ${ }^{31}$ who does not explicitly mention the

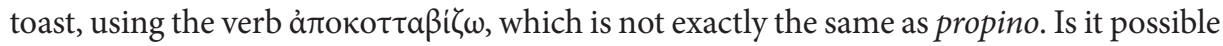
that Cicero did not fully understand the meaning of Theramenes' deed?

There were two variants of the game of кó $\tau$ Taßos. In both of them, the player was supposed to name the object of his love and toss the dregs remaining in his wine cup at a target: either a metal disc on top of a candelabrum, or small, empty vinegar-saucers floating in a bowl. In the first instance, the player strove to ring the disc by making it fall on another, smaller disc halfway down the candelabrum; in the second instance, his goal

25 Thus Andrewes (1953: 3 n. 7), followed by McCoy (1970: 126, n. 49); Ostwald (1986: 400, n. 215); Kagan (1987: 206); Rhodes (2011: 85).

26 Thus, e. g., Grote (1855: 104 n. 1); Busolt (1904: 1510 n. 1); Beloch (1914: 391 n. 1); Hatzfeld (1951: 256-258); Barbieri (1956: 56 and 66); Sartori (1957: 125); Bleckmann (1998: 388-389); Heftner (2011: 221 n. 47).

27 Nep. Alc. 5, 5-7. In Alc. 5, 6, he says the three generals recovered many cities on Asian coast. It is probable that Nepos is simply wrong, although a change of the transmitted Asiae to Thraciae suggested by Nipperdey (see the apparatus of Marchant [1985: 25]), would exonerate him.

28 Nep. Alc. 6, 3. For other descriptions of Alcibiades' return to Athens, see Xen. Hell. I, 4, 12-20; Diod. Sic. XIII, 68, 2-6; Plut. Alc. 32, 1-34, 2; Iust. V, 4, 9-18.

29 Stem (2012: 23 with $\mathrm{n}$. 74, where see references) rightly dismisses attempts at detailed reconstruction of Nepos' oeuvre as inconclusive speculation.

30 Cic. Tusc. I, 96-97: quam illud iter iucundum esse debet, quo confecto nulla reliqua cura, nulla sollicitudo futura sit! quam me delectat Theramenes! quam elato animo est! etsi enim flemus, cum legimus, tamen non miserabiliter vir clarus emoritur: qui cum coniectus in carcerem triginta iussu tyrannorum venenum ut sitiens obduxisset, reliquum sic e poculo eiecit, ut id resonaret, quo sonitu reddito adridens 'propino' inquit 'hoc pulchro Critiae', qui in eum fuerat taeterrimus. (97) Quis hanc maximi animi aequitatem in ipsa morte laudaret, si mortem malum iudicaret? vadit enim in eundem carcerem atque in eundem paucis post annis scyphum Socrates, eodem scelere iudicum quo tyrannorum Theramenes...

31 Xen. Hell. II, 3, 56. 
was to sink as many of the saucers in the bowl as he could. If the player achieved his goal, it was considered a good omen for his love. ${ }^{32}$

The most recent commentator on the Ciceronian passage states that "if [...] Theramenes threw the wine and was not expecting to hit the mark on account of the difficulty of the attempt, he would have been surprised and so laughed at his discovery that fortune had given him a sign; he told the man nearby (likely the one who gave him the poison) that he would requite Critias for the love he bore him (rather than simply toast to his health ironically, as most editors)." 33 Two notes are necessary. First, there was no target in the prison Theramenes could have hit; Xenophon's á

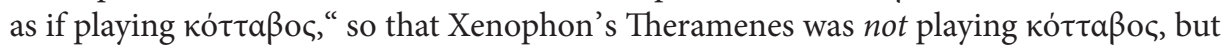
toasting ironically. We do not know what the subject of resonaret was according to Cicero, but in all probability it was some object usually located in the prison, not the metal disc

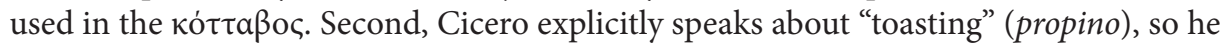
did understand Theramenes' words as an ironic toast. Consequently, whatever Cicero

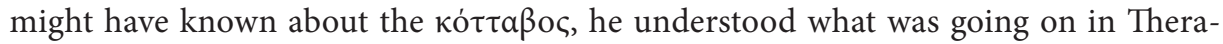
menes' prison quite well.

But was Xenophon the source of Cicero's information about the incident? Scholars have been sceptical, and it has been claimed that Cicero's source was a popular treatise on philosophy. ${ }^{34}$ If so, we cannot say whether or not he misinterpreted his source, although on the basis of the evidence presented earlier, it does not seem likely.

Shortly after mentioning Theramenes' courage, Cicero places him on a par with Socrates, calling them both praestantis viros virtutis et sapientiae gloria, which is one of the most explicit instances of praise for Socrates in the whole of Cicero's extant oeuvre. ${ }^{35}$ To be compared with the pater or parens philosophiae is definitely a great honour, ${ }^{36}$ but we should not forget that in this passage, Cicero is praising their courage in the face of death, not making an overall judgement about their lives.

32 See, e. g., Schneider (1922); Sparkes (1960); Hoesch (1990); Csapo-Miller (1991: esp. 47-49); Jacquet-Rimassa (1995).

33 Kennedy (2010: 199), who otherwise elucidates the passage with admirable precision and succinctness.

34 See Münscher (1920: 47 and 76), cited approvingly by Breitenbach (1967: 1902 and 1904). Pesely (1983: 464 n. 328) claimed that this Ciceronian passage was used by Valerius Maximus (Val. Max. III, 2 ext. 6), but I think Valerius used the same source as Cicero, for Valerius' version is more detailed than that of Cicero, witness e. g. the mention of a public slave.

35 Cic. Tusc. I, 100. Cf. Cic. Nat. deor. III, 82: quid dicam de Socrate, cuius morti inlacrimare soleo Platonem legens?

36 I found no comprehensive study of Socrates' image in Cicero's writings. For instance, Glucker (1997) examines how the disputes of Hellenistic philosophers about Socrates' irony are mirrored in Cicero's philosophical treatises; Döring (1998: 166-178) has nothing to say about Cicero. But while the Roman orator did not endorse everything he considered Socratic (see esp. De orat. I, 42 and III, 60-62 and Tusc. V, 30), he called Socrates parens philosophiae (Fin. II, 1, 6, Nat. deor. I, 93) or princeps philosophiae (Tusc. V, 47, Nat. deor. II, 167), the best possible guide (Div. I, 122; Att. VIII, 2, 4), and the founder of the true philosophy (Tusc. IV, 6). Cicero also declares that Socrates and Plato overcome other philosophers by their sheer authority (Div. I, 62; cf. Tusc. I, 55) and reproduces the Delphic oracle about Socrates' wisdom (Cato 78); and see Cicero's thankful apostrophe in Att. XIV, 9,1 . 
Cicero names Theramenes in other writings as well. It appears that the Romans of Cicero's time remembered Theramenes mostly as an accomplished orator. ${ }^{37}$ Cicero mentions him in such a context three times: in the second book of his De Oratore, Theramenes appears along with Critias and Lysias as a representative of the generation who came after Pericles, Alcibiades and Thucydides, and who retinebant illum Pericli sucum, sed erant paulo uberiore filo..$^{38}$ Now we do not have reliable evidence for the date of birth of any of these men, ${ }^{39}$ but it is clear that Pericles was at least a generation older than Alcibiades, and it is highly probable that Thucydides, Critias, Alcibiades, Theramenes, and Lysias were all born between 460 and $440 .{ }^{40}$ So Cicero's generational scheme is quite muddled.

In the third book of the same treatise, Theramenes is mentioned along with Themistocles and Pericles as orators who propter ... faciendi dicendique sapientiam florerent,${ }^{41}$ and one can hardly question the veracity of this statement.

Finally, in Brutus, Cicero labelled Theramenes along with Critias and Alcibiades as near contemporaries of Cleon, whose oratory can best be judged from the work of Thucydides, and then went on to criticise their style. ${ }^{42}$ Here the chronology is easier to accept than in De Oratore.

Before we examine the foundations of Cicero's aesthetic judgment, it is to be noted that he was not the only Roman who appreciated Theramenes' style: according to Plutarch, Caesar in his Anticato praised Cicero's oratory and compared it with that of Pericles and Theramenes. ${ }^{43}$

The fame of Theramenes the orator is somewhat surprising in the face of another of Cicero's statements in the second book of De Oratore: multa Lysiae scripta sunt, nonnulla Critiae, de Theramene audimus. ${ }^{44}$ How can one praise Theramenes' oratory without actually having read anything he wrote? Scholars have long ago rightly dismissed the tra-

37 Contemporary Greek rhetoricians do not seem to have been interested in Theramenes. Dionysius of Halicarnassus mentions him only as a putative teacher of Isocrates (Dion. Hal. Isoc. 1, 2, with cautious

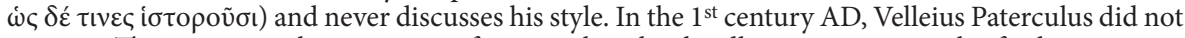
mention Theramenes in his overview of orators, but that hardly carries any weight, for he mentions no Greek apart from Isocrates (I, 16, 4).

38 Cic. De orat. II, 93.

39 The ancient tradition put Lysias' date of birth in 459/8 (Dion. Hal. Lys. 1, 4; [Plut.] Mor. 835c), but 445 seems more likely, see, e. g., Dover (1968: 28-43) or Todd (2007: 6-12); for a defence of an earlier date, see Schindel (1967) and more persuasively Verlinsky (2014: esp. 158-177).

40 If we would wish to make Thucydides the contemporary of Pericles, we would have had to take seriously the possibility that the historian of the Peloponnesian war is identical with the general active in the Samian war (Thuc. I, 117, 2), which is not very likely, see Samons (2016: 133). On the shaky foundation of the dramatic date of Plato's Charmides, Critias' date of birth was assumed to be in c. 460 by Davies (1971: 327) and Nails (2002: 108-109). We simply do not know how old Theramenes was when he was first mentioned in Eupolis' comedy Poleis, probably in 422 (Eup. fr. 215 PCG). For Lysias, see the preceding note.

41 Cic. De orat. III, 59.

42 Cic. Brut. 28-29: Cleonem etiam temporibus illis turbulentum illum quidem civem, sed tamen eloquentem constat fuisse. (29) Huic aetati suppares Alcibiades Critias Theramenes; quibus temporibus quod dicendi genus viguerit ex Thucydidi scriptis, qui ipse tum fuit, intellegi maxume potest. grandes erant verbis, crebri sententiis, compressione rerum breves et ob eam ipsam causam interdum subobscuri.

43 Pesely (1983: 464 n. 333) thinks that "Perhaps Caesar deliberately framed this allusion to Perikles and Theramenes so as to flatter Cicero by showing his familiarity with the De Oratore." It is possible; Themistocles might be missing because his life ended in exile. But Caesar's familiarity with Greek literature surely was not dependent on Cicero's writings, and note that Caesar's praise of Cicero was probably ironical, see, e. g., Schauer (2016: 62-63), dealing with another passage from the Anticato.

44 Cic. De orat. II, 93. 
dition which made Theramenes author of rhetorical treatises, ${ }^{45}$ and there is no reason to suppose Cicero read any of these. Nor can we deduce anything from an isolated remark of the $11^{\text {th }}$-century Byzantine scholar John Doxapatres, who claimed that Theramenes wrote

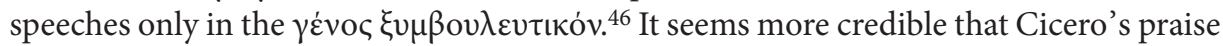
of Theramenes was based on Theramenes' speech as recorded by Xenophon in his Hellen-

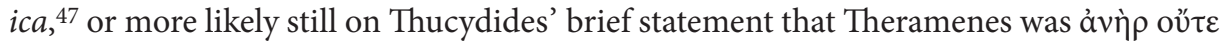

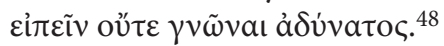

We have seen that Cicero admired Theramenes' courage in the face of death and considered him an accomplished orator. Cicero had his own reasons for sympathizing with an orator-politician who often changed allegiances in order to promote what he thought best for himself, and for his country. Yet Cicero also knew that Theramenes was one of the two leading figures among the thirty tyrants, and he repeatedly couples Theramenes with Critias, the worst tyrant of Athenian history. For this reason, I would hesitate to claim that "Cicero shows no ambivalence about Theramenes; he is unreservedly favorable." 49 I would prefer to say that Cicero would not have agreed with everything Theramenes did; but chose not to mention it.

As a conclusion, how can we explain that Theramenes easily overshadowed the other three Athenian oligarchs? Athenian history might have been mentioned occasionally during political debates in Rome, ${ }^{50}$ but the Romans did not usually invoke the Greeks as politicians worth imitating. ${ }^{51}$ Accordingly, they focused on the artistic achievements of Antiphon and Theramenes, on the book of dream-interpretation perhaps written by the former and on the moral exemplum furnished by the latter in the face of death. Cicero's contemporaries were not interested in trying to give an overall assessment of the Athenian oligarchs' political careers. They had their own history to make.

45 [Plut.] Mor. 837a has Isocrates collaborate with Theramenes on rhetorical writings attributed to someone called Boton. The Byzantine lexicon Suda has four articles on Theramenes, the first of which

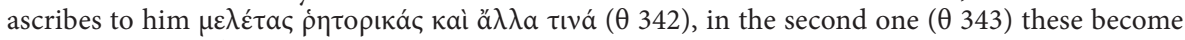

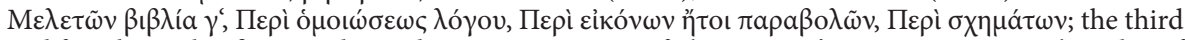
and fourth articles, $\theta 344$ and 345, do not mention any of Theramenes' putative writings. The value of these testimonies was dismissed by Wilamowitz-Moellendorff (1893: 167 n. 69) and Schwahn (1934: 2318), though I am puzzled by words of the latter: "im Altertum keine Schriften von T[heramenes] bekannt waren, obwohl er einen begründeten [!] Ruf als Redner besaß”.

46 See Rabe (1931: 129-130). Wilamowitz-Moellendorff (1893: 167 n. 69) thought this worthy of attention and suggested (without much confidence) that it contained a kernel of ancient tradition that might have led some Peripatetic philosopher (say, Theophrastus) to give Theramenes prominence in the history of rhetoric.

47 Xen. Hell. II, 3, 35-49. But Cicero might not have read these, see above, n. 34.

48 Thuc. VIII, 68, 4. I am confident Cicero read Thuc. VIII, 68, 2, see my comments on Cic. Brut. 47 above (pp. 31-32).

49 Pesely (1983: 46).

50 For perhaps the most famous incidents, see Sall. Catil. 51, 28-31 (Caesar's speech) and Cic. Phil. I, 1, Vell. II, 58, 4, Plut. Cic. 42, 3, and Dio Cass. XLIV, 22, 3-34, 1 (Cicero's recommendation of amnesty for Caesar's assassins). I am not aware of any mention of the oligarchy of the Four Hundred by a Roman before Iust. V, 3, 5 .

51 See esp. Sallust's sneering dismissal of the importance of the Athenians' political achievements in Sall. Catil. 8, 2-4. 


\section{REFERENCES}

Andrewes, A., 1953. 'The Generals in the Hellespont'. The Journal of Hellenic Studies 73, 2-9.

Andriolo, N., 2004. Magistrature ad Atene dal 413 al 401. a. C. Padova: Sargon.

Ax, W. (ed.), 1938. M. Tulli Ciceronis scripta quae manserunt omnia. Fasc. 46: De divinatione, De fato, Timaeus. Leipzig: B. G. Teubner.

Barbieri, G., 1956. 'Alcibiade e le strategie dal 411 al 408'. In: Studi in onore di Aristide Calderini e Roberto Paribeni. Milano: Ceschina, 51-68.

Beloch, K. J., 1914. Griechische Geschichte. Zweiter Band. Bis auf die sophistische Bewegung und den Peloponnesischen Krieg. Erste Abteilung. Strassburg: Karl J. Trübner.

Bleckmann, B., 1998. Athens Weg in die Niederlage. Die letzten Jahre des Peloponnesischen Kriegs. Stuttgart / Leipzig: B. G. Teubner.

Breitenbach, H. R., 1967. 'Xenophon 6'. In: Paulys Realencyclopädie der classischen Altertumswissenschaft IX A 2. Stuttgart: Alfred Drückenmüller Verlag, 1569-2052.

Busolt, G., 1904. Griechische Geschichte biz zur Schlacht bei Chaeroneia. Band III. Teil II: Der peloponnesische Krieg. Gotha: Friedrich Andreas Perthes.

Canfora, L., 1970. Tucidide continuato. Padova: Antenore.

Canfora, L., 1999. Il mistero Tucidide. Milano: Adelphi.

Canfora, L., 2006. 'Author, Contexts, Ideas'. In: A. Rengakos, A. Tsakmakis (eds.), Brill's Companion to Thucydides. Leiden / Boston: Brill, 3-32.

Canfora, L., 2011. Il mondo di Atene. Bari: Gius, Laterza \& Figli.

Csapo, E., Miller, M. C., 1991. 'The "Kottabos-Toast" and an Inscribed Red-Figured Cup'. Hesperia 60, 367-382.

Davies, J. K., 1971. Athenian Propertied Families 600-300 B. C. Oxford: Clarendon Press.

Döring, K., 1998. 'Sokrates, die Sokratiker und die von ihnen begründeten Traditionen'. In: H. Flashar (ed.), Grundriss der Geschichte der Philosophie. Die Philosophie der Antike. Band 2/1. Sophistik, Sokrates, Sokratik, Mathematik, Medizin. Basel: Schwabe, 139-364.

Dover, K. J., 1968. Lysias and the Corpus Lysiacum. Berkeley / Los Angeles: University of California Press.

Dover, K. J., 1981. 'Appendix ii: Strata of Composition'. In: A. W. Gomme, A. Andrewes, K. J. Dover, A Historical Commentary on Thucydides. Volume V. Oxford: Oxford University Press, 384-444.

Gagarin, M., 2002. Antiphon the Athenian: Oratory, Law, and Justice in the Age of the Sophists. Austin: University of Texas Press.

Giomini, R. (ed.), 1975. M. Tulli Ciceronis scripta quae manserunt omnia. Fasc. 46: De divinatione, De fato, Timaeus. Leipzig: B. G. Teubner.

Glucker, J., 1997. 'Socrates in the Academic Books and Other Ciceronian Works'. In: B. Inwood, J. Mansfeld (eds.), Assent and Argument. Studies in Cicero's Academic Books. Proceedings of the Seventh Symposium Hellenisticum (Utrecht, August 21-25, 1995) [= Philosophia Antiqua 76]. Leiden: Brill, 58-88.

Grossi, G., 1984. Frinico tra la propaganda democratica e guidizio Tucidideo. Roma: «L'Erma» di Bretschneider.

Grote, G., 1855. A History of Greece. Volume VIII. London: John Murray.

Hatzfeld, J., 1951. Alcibiade: Étude sur l'histoire d'Athènes à la fin du Ve siècle. Paris: Presses Universitaires de France.

Heftner, H., 2001. Der oligarchische Umsturz des Jahres 411 v.Chr. und die Herrschaft der Vierhundert in Athen. Quellenkritische und historische Untersuchungen. Frankfurt am Main: Peter Lang.

Heftner, H., 2011. Alkibiades: Staatsmann und Feldherr. Darmstadt: Wissenschaftliche Buchgesellschaft.

Hoesch, N., 1990. 'Das Kottabosspiel'. In: K. Vierneisel, B. Kaeser (eds.), Kunst der Schale - Kultur des Trinkens. München: Grebner Anscheim, 272-275.

Hornblower, S., 2008. A Commentary on Thucydides. Volume III: Books V.25-VIII.109. Oxford: Clarendon Press.

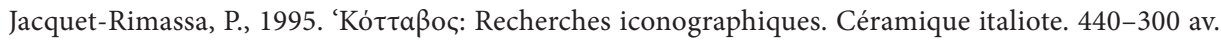
J.-C.'. Pallas 42, 129-165.

Kagan, D., 1987. The Fall of the Athenian Empire. Ithaca / London: Cornell University Press. 
Keaney, J. J., 1980. 'Hignett's HAC and the authorship of the Athenaion politeia'. Liverpool Classical Monthly 5, 51-56.

Kennedy, S. M., 2010. M. Tulli Ciceronis Tusculanarum disputationum de libro primo commentarius. Dissertation. Exeter.

Kriegel, J., 1909. Der Staatsstreich der Vierhundert. Dissertation. Bonn.

Lapini, W., 1991. 'Tucidide rimpatriato'. Studi italiani di filologia classica 84, 9-51.

Laughton, E., 1961. 'Cicero and the Greek orators'. The American Journal of Philology 82, 27-49.

Marchant, P. K. (ed.), 1985. Cornelii Nepotis vitae cum fragmentis. Leipzig: B. G. Teubner.

McCoy, W. J., 1970. Theramenes, Thrasybulus and the Athenian Moderates. Dissertation. Yale.

Mewes, W., 1868. Untersuchungen über das achte Buch der Thukydideischen Geschichte. Brandenburg: Adolph Müller.

Monge, D., 1995. 'L'affermazione dei gruppi antidemocratici alla vigilia del colpo di stato dei Quattrocento'. Quaderni del Dipartimento di Filologica, Linguistica e Tradizione Classica dell' Università di Torino 4, 23-39.

Münscher, K., 1920. Xenophon in der griechisch-römischen Literatur. Leipzig: Dietrich.

Nails, D., 2002. The People of Plato: A Prosopography of Plato and Other Socratics. Indianapolis: Hackett.

Nývlt, P., 2014. 'Sparta and Persia between the Second and the Third Treaty in 412/411 BCE: A Chronology.' Eirene 50, 39-60.

Ostwald, M., 1986. From Popular Sovereignty to the Sovereignty of Law. Berkeley / Los Angeles / London: University of California Press.

PCG = Poetae comici Graeci. Ediderunt R. Kassel et C. Austin. Berolini / Novi Eboraci: Walter de Gruyter, 1983-.

Pendrick, G. J. (ed.), 2002. Antiphon the Sophist, The fragments. Cambridge: Cambridge University Press.

Pesely, G. E., 1983. Theramenes and the Athenian Politics: A Study in the Manipulation of History. Dissertation. Berkeley.

Rabe, H. (ed.), 1931. Prolegomenon sylloge (accedit Maximi libellus de obiectionibus insolubilibus) [= Rhetores graeci. Volumen XIV]. Leipzig: B. G. Teubner.

Rhodes, P. J., 1981. A Commentary on the Aristotelian Athenaion Politeia. Oxford: Clarendon Press.

Rhodes, P. J., 2011. Alcibiades: Athenian Playboy, General and Traitor. Barnsley: Pen and Sword Military.

Samons II, L. J. 2016. Pericles and the Conquest of History: A Political Biography. Cambridge: Cambridge University Press.

Sartori, M., 1957. Le eterie nella vita politica ateniese del VI e V secolo a. C. Roma: «L’Erma» di Bretschneider.

Schauer, M., 2016. Der Gallische Krieg: Geschichte und Täuschung in Caesars Meisterwerk. München: C. H. Beck.

Schindel, U., 1967. 'Untersuchungen zur Biographie des Redners Lysias'. Rheinisches Museum für Philologie 110, 32-52.

Schneider, K., 1922. 'Kottabos'. In: Paulys Real-Encyclopädie der classischen Altertumswissenschaft XI 2. Stuttgart: J. B. Metzlersche Verlagsbuchhandlung, 1528-1541.

Schwahn, W., 1934. 'Theramenes 1'. In: Paulys Realencyclopädie der classischen Altertumswissenschaft V A 2. Stuttgart: Alfred Drückenmüller Verlag, 2304-2320.

Shear, J. L., 2011. Polis and Revolution: Responding to Oligarchy in Classical Athens. Cambridge: Cambridge University Press.

Sparkes, B. A., 1960. 'Kottabos, an Athenian after-dinner game'. Archaeology 13, 202-207.

Steinbock, B., 2013. Social Memory in Athenian Public Discourse: Uses and Meanings of the Past. Ann Arbor: University of Michigan Press.

Stem, R., 2012. The Political Biographies of Cornelius Nepos. Ann Arbor: University of Michigan Press.

ThLL = Thesaurus linguae Latinae. Lipsiae; München; Berlin / New York, 1900-.

Todd, S. C., 2007. A Commentary on Lysias: Speeches 1-11. Oxford: Oxford University Press.

Verlinsky, A., 2014. 'Lysias' Chronology and the Dramatic Date of Plato's Republic'. Hyperboreus 20, 158-198.

Wade-Gery, H. T., 1949. ‘Thucydides'. In: M. Cary (ed.), The Oxford Classical Dictionary, Oxford: Clarendon Press, 902-905. 
Wade-Gery, H. T., 1996. 'Thucydides 2'. In: S. Hornblower, A. Spawforth (eds.), The Oxford Classical Dictionary. $3^{\text {rd }}$ ed. Oxford: Oxford University Press, 1516-1519.

Wardle, D., 2006. Cicero: On divination, Book 1. Oxford: Clarendon Press.

Wilamowitz-Moellendorff, U. von, 1893. Aristoteles und Athen. Erster Band. Berlin: Weidmannsche Buchhandlung.

Wilamowitz-Moellendorff, U. von, 1919. 'Das Bündnis zwischen Sparta und Athen'. In: Sitzungsberichte der preussischen Akademie der Wissenschaften, 934-957.

Wilamowitz-Moellendorff, U. von, 1969. 'Das Bündnis zwischen Sparta und Athen'. In: Kleine Schriften III. Griechische Prosa. Berlin: Akademie Verlag, 380-405.

\section{VEDOUCÍ PŘEDSTAVITELÉ ČTYŘ SET V DÍLECH CICERONA A JEHO ŘÍMSKÝCH SOUČASNÍKŮ}

Článek se zabývá zmínkami o Peisandrovi, Frýnichovi, Antifóntovi a Thérámenovi v dílech Cicerona a Cornelia Nepota. Historická spolehlivost tvrzení rímských autorů je dosti proměnlivá a musí být posuzována individuálně. Při rekonstrukci názorů Rímanů na řecké politiky je třeba postupovat opatrně, protože se nikdy nesnažili hodnotit celé jejich působení.

\section{Pavel Nývlt}

Institute of Philosophy, The Czech Academy of Sciences, Prague

nyvlt@ics.cas.cz 